\title{
OPEN Author Correction: BICORN: An R package for integrative inference of de novo cis-regulatory modules
}

Xi Chen, Jinghua Gu, Andrew F. Neuwald, Leena Hilakivi-Clarke, Robert Clarke \& Jianhua Xuan

Correction to: Scientific Reports https://doi.org/10.1038/s41598-020-63043-2, published online 14 May 2020

The original version of this Article contained errors.

In the Abstract,

"Genome-wide transcription factor (TF) binding signal analyses reveal co-localization of TF binding sites based on inferred cis-regulatory modules (CRMs)."

now reads:

"Genome-wide transcription factor (TF) binding signal analyses reveal co-localization of TF binding sites, based on which cis-regulatory modules (CRMs) can be inferred."

In addition, in the Methods section, under the subheading 'BICORN input',

"Binary TF-gene binding input is used because it is the signal format most commonly used by different resources."

now reads:

"Binary TF-gene binding input is used because it is the signal format most commonly provided by different resources.”

Finally, the Acknowledgements section in this Article was incomplete.

“This work was supported by National Institutes of Health (NIH) grants CA149653 (to JX), CA164384 (to LHC) and CA149147 (RC), and by NIH-NIGMS grant R01GM125878 to AFN."

now reads:

“This work was supported by National Institutes of Health (NIH) grants CA149653 (to JX), CA164384 (to LHC) and CA149147 (RC), and by NIH-NIGMS grant R01GM125878 to AFN. Note that open access publishing is supported by "VT Open Access Subvention Fund"."

These errors have now been corrected in the HTML and PDF versions of the Article. 
(1) Open Access This article is licensed under a Creative Commons Attribution 4.0 International cc) License, which permits use, sharing, adaptation, distribution and reproduction in any medium or format, as long as you give appropriate credit to the original author(s) and the source, provide a link to the Creative Commons licence, and indicate if changes were made. The images or other third party material in this article are included in the article's Creative Commons licence, unless indicated otherwise in a credit line to the material. If material is not included in the article's Creative Commons licence and your intended use is not permitted by statutory regulation or exceeds the permitted use, you will need to obtain permission directly from the copyright holder. To view a copy of this licence, visit http://creativecommons.org/licenses/by/4.0/.

(C) The Author(s) 2020 